\title{
Osmotic Fragility of Bacteria Deprived of Carbon Dioxide
}

\author{
By B. K. CHOE AND G. BERTANI \\ Department of Microbial Genetics, Karolinska Institutet, Stockholm 6o, Sweden
}

(Accepted for publication 29 May 1968)

SUMMARY

An absolute requirement for external carbon dioxide can easily be demonstrated for Escherichia coli strains B, C and K-12, and for a Serratia marcescens strain under anaerobic conditions, even in the presence of a very rich complex medium. During carbon dioxide deprivation such bacteria (with the exception of $E$. coli B) become extremely sensitive to the challenge of a sudden decrease in the osmotic pressure of the medium. This challenge does not seem to disrupt the gross structure of the bacteria, but it impairs in an apparently irreversible manner their ability to multiply.

\section{INTRODUCTION}

In the course of some experiments on bacteriophage infection of anaerobically growing bacteria, we accidentally observed a phenomenon which to our knowledge has not been noted before, and which we briefly characterize in this paper. We show that in some bacteria growing under anaerobic conditions in a very rich, complex medium, $\mathrm{CO}_{2}$-deprivation produces a state of extreme osmotic fragility.

\section{METHODS}

Organisms. The following bacteria were used. Escherichia coli strain c: derivatives C-Ia (Sasaki \& Bertani, 1965), C-I055 (which is $\mathrm{F}^{+}$, streptomycin resistant, and polyauxotrophic), and C-ro7 (like c-ra, but lysogenic for phage $\mathrm{P}_{2}$ ). $E$. coli strain K-I2: derivatives c600 (Appleyard, 1954), c600 lysogenic for phage $\lambda$, and CAI54 (Brenner \& Beckwith, 1965) cured of phage $\lambda$ by hetero-immune superinfection (by D. Walker). Escherichia coli strain B and its derivatives: B-I (made lysogenic for P2 and simultaneously cured of the dismune proplage of Cohen, 1959), B-I6 (made radiation resistant by the method of Witkin, I947) and B-I7 (BC of Cohen, 1959 also made radiation resistant). Serratia marcescens strain SA-I8 (Bertani, Torheim \& Laurent, 1967).

In addition, two biotin-requiring mutants of Escherichi coli (C-I $20 \mathrm{I}$ and C-I202) were isolated after treatment with the mutagen $N$-mehtyl- $N^{\prime}$-nitro- $N$-nitrosoguanidine (Mandell \& Greenberg, 1960; method of Adelberg, Mandel \& Chen, 1965) from E. coli strain C-3 (Bertani \& Six, 1958). Both have low reversion frequencies. Biotinstarved cultures, following residual growth, maintain a constant viable count for periods of the order of 5 to $8 \mathrm{hr}$ after which morphologically anomalous forms appear. C-I 201 bacteria have a greater tendency than C-I202 to develop into filamentous forms when starved of biotin. Both mutations are transducible by phage $\lambda$ (see Del CampilloCampbell, Kayajanian, Campbell \& Adhya, 1967). 
Unless otherwise stated, the observations to be described refer to Escherichia coli strain C-Ia.

Media. Unless otherwise specified, bacteria were grown in LB medium (I \% Sheffield Chemicals' N-Z-amine type B, $0.5 \%$ yeast extract, I $\% \mathrm{NaCl}, 0.1 \%$ glucose; Bertani, 195I), which is nutritionally, a very rich medium. This medium was adjusted at about $\mathrm{pH}_{7 \cdot 2}$. Viable assays were made on LB agar with the soft agar overlay technique, as for phage work. The melted soft agar was held at $45^{\circ}$ in small tubes until needed. In some experiments tryptone broth (Sasaki \& Bertani, 1965) and DIL (0.I \% Difco nutrient broth, $0.5 \% \mathrm{NaCl}$ ) were used.

A defined medium (Davis; in Sasaki \& Bertani, 1965) with the appropriate supplements was used in work with the biotin-requiring mutants. A biotin concentration of $0.01 \mu \mathrm{g} . / \mathrm{ml}$. was more than sufficient for normal growth of the mutants. The effects of biotin deprivation were studied in Davis medium supplemented with half strength Biotin Assay Medium (Difco).

Cultural techniques. All incubation was at $37^{\circ}$. Anaerobic growth was obtained by bubbling a tube culture with a mixture of $\mathrm{N}_{2}+\mathrm{CO}_{2}(95+5, \%, v / v) . \mathrm{CO}_{2}$-free $\mathrm{N}_{2}$ was obtained by bubbling $\mathrm{N}_{2}$ first through two gas-washing bottles, each containing half litre of $30 \% \mathrm{NaOH}$ solution, and then through a $\mathrm{I} / \mathrm{IO}$ saturated $\mathrm{Ba}(\mathrm{OH})_{2}$ solution in a large test tube (to detect inefficient $\mathrm{CO}_{2}$ removal).

Standard experiment. An overnight static broth culture was diluted 200-fold into fresh broth and incubated anaerobically. When the bacterial count, as judged by counting with a microscope, had increased to between $5 \times 10^{7}$ and $10^{8}$ bacteria $/ \mathrm{ml}$, the culture was again diluted (10- to 50-fold) in fresh broth ( 5 to $15 \mathrm{ml}$. in a large test tube) held at $37^{\circ}$ and already equilibrated with the desired gas (either the $\mathrm{N}_{2}+\mathrm{CO}_{2}$ mixture or $\mathrm{CO}_{2}$-free $\mathrm{N}_{2}$ ) by bubbling it for 15 to $30 \mathrm{~min}$. Bubbling was continued at a rate of about $200 \mathrm{ml}$. gas/min. At various times throughout the experiment, samples of the culture were taken and colony counts made immediately following a dilution either in broth (control) or in distilled water (osmotic challenge) or in other media held at room temperature.

$\beta$-Galactosidase assay (Wallenfels, 1962). Bacteria resuspended in $0 . \mathrm{I}$ M-sodium phosphate buffer ( $\mathrm{pH} \mathrm{7.4)}$ ) were shaken with I/IO volume of toluene at $42^{\circ}$ for $15 \mathrm{~min}$. A sample ( $0.1 \mathrm{ml}$.). of the suspension was then added to $3 \mathrm{ml}$. of a solution of $o$-nitrophenyl- $\beta$-D-galactopyranoside (Sigma Chemical Co., St Louis, Missouri) and incubated for $20 \mathrm{~min}$. at $42^{\circ}$. The extinction was read in a colorimeter at $405 \mathrm{~m} \mu$. A suspension containing the same amount of carrier (see Table 4) bacteria of the CAI54 derivative, which is unable to synthesize $\beta$-galactosidase was treated in exactly the same manner and used as a blank.

\section{RESULTS}

Escherichia coli strain C-Ia, used in most of the experiments to be described, grows about equally well in broth (yield at saturation: 3 to $6 \times 10^{8}$ viable bacteria $/ \mathrm{ml}$; maximum doubling rate: $20-22 \mathrm{~min}$.) under aerobic as under anaerobic conditions. When, however, $\mathrm{CO}_{2}$ is removed from an anaerobic, exponentially growing broth culture, by vigourously bubbling it with $\mathrm{CO}_{2}$-free $\mathrm{N}_{2}$, two phenomena can be observed (Fig. I): (a) multiplication of the bacteria, as measured by viable count following appropriate dilution in broth, comes to a halt; $(b)$ the bacteria become highly sensitive to a challenge consisting of a sudden dilution (usually $\mathrm{I} / \mathrm{IOO}$ ) in distilled water. 
To demonstrate these phenomena, the bacterial concentration during $\mathrm{CO}_{2}$-starvation must not be much above $10^{7}$ bacteria/ml. The reason for this is, we believe, that the $\mathrm{CO}_{2}$ released by the bacteria into the medium is efficiently re-utilized by other bacteria before it can be removed by the bubbling gas. The two phenomena are largely unaffected by minor $\mathrm{pH}$ changes in the medium (Fig. I). They were also demonstrated in tryptone broth, in the medium used in the biotin-deprivation experiments (see below), and even in simple defined media, although in this case the osmotic fragility was erratic and less pronounced. They could not be demonstrated under aerobic conditions.

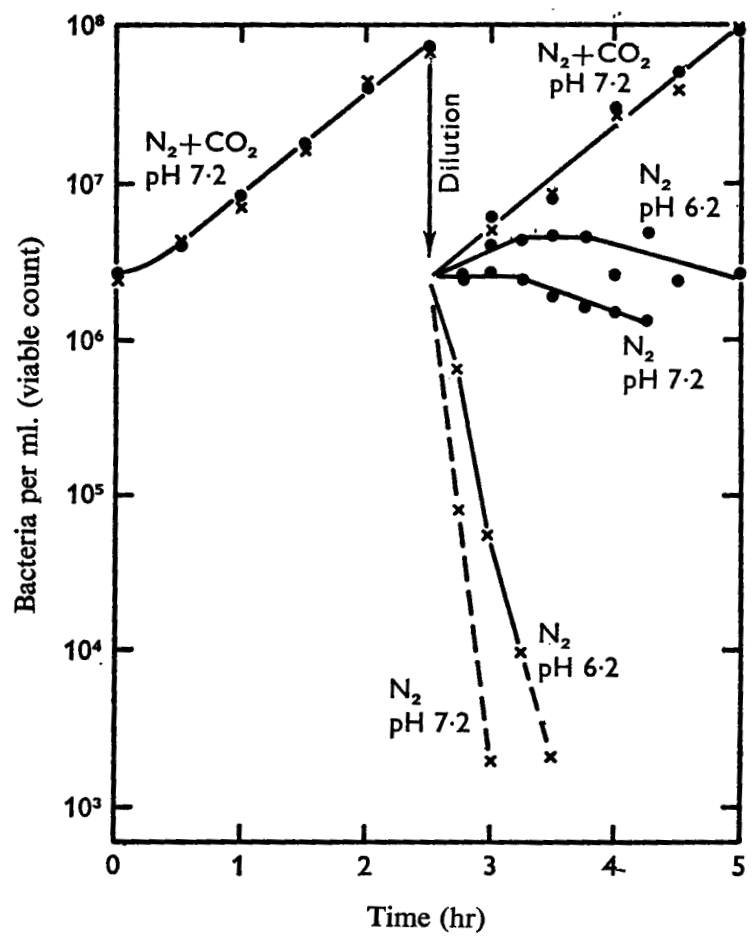

Fig. I. Inhibition of multiplication and appearance of osmotic sensitivity in anaerobically growing Escherichia coli following removal of $\mathrm{CO}_{2}$. Standard experiment: at $2.5 \mathrm{hr}$ the culture was diluted $1 / 50$ to establish three parallel cultures differing in gas régime and in initial broth $\mathrm{pH}$ value. $\bullet$, viable counts following dilution in broth; $x$, viable counts following dilution in distilled water. The first dilution step was $I / 100$ in all cases.

When the experiment is continued beyond the time shown in Fig. I, the viable counts in the $\mathrm{CO}_{2}$-deprived cultures begin to decrease after 2 to $3 \mathrm{hr}$, even in the absence of challenge, and eventually reach the same low values observable after challenge.

The sensitivity to the challenge of dilution in water appears to be really an osmotic phenomenon. Simple defined media with sufficiently high solute concentrations are as good as broth as diluents, whereas half-strength broth behaves like water (Table I).

The osmotic sensitivity does not develop immediately upon dilution into broth deprived of $\mathrm{CO}_{2}$, but takes at least $30 \mathrm{~min}$. to reach its full expression. Chloram- 
phenicol, an inhibitor of protein synthesis, added at the time when $\mathrm{CO}_{2}$-deprivation begins, does not permit the development of the osmotic sensitivity (Table 2). No evidence of protection was found when the culture was exposed to chloramphenicol for a period of $2 \mathrm{hr}$ just before $\mathrm{CO}_{2}$-deprivation. These observations suggest that the development of osmotic sensitivity results from unbalanced synthesis.

\section{Table I. Effect of diluent composition on the survival of anaerobically growing Escherichia coli $\mathrm{C}-\mathrm{Ia}$ deprived of $\mathrm{CO}_{2}$}

Standard experiment: results of viable count (colony count) assays made $\mathrm{I} \mathrm{hr}$ after the beginning of $\mathrm{CO}_{2}$ deprivation, with various diluents (held at room temperature). The first dilution step was in all cases $1 / 10$. The $100 \%$ value is set equal to the titre of the culture at the beginning of $\mathrm{CO}_{2}$ deprivation. Values greater than $100 \%$ result from the residual multiplication that could occur under these conditions (see, for example, Fig. 1). (a), (b), and (c) are different experiments. LB or DIL, preceded by a multiplication factor, indicates a medium with the same qualitative composition as LB or DIL, but differing in total solute concentration, the normal concentration being taken as $I \cdot O$.

Percentage original colony count

\begin{tabular}{lccc}
\cline { 2 - 4 } Composition of the diluent used & $(a)$ & $(b)$ & $(c)$ \\
LB & 42 & 170 & IIo \\
I.5 LB & 150 & - & 90 \\
$2.0 \mathrm{LB}$ & 110 & - & 90 \\
$0.5 \mathrm{LB}$, or $0.25 \mathrm{LB}$, or $0.1 \mathrm{LB}$ & $c a .0 .5$ & - & $\mathrm{ca} .0 .0 \mathrm{I}$ \\
Distilled water & - & 0.1 & - \\
DIL & - & 0.2 & - \\
$4 \%$ sucrose in $0.83 \mathrm{DIL}$ & - & 135 & - \\
$8 \%$ sucrose in $0.67 \mathrm{DIL}$ & - & 115 & - \\
$12 \%$ sucrose in $0.5 \mathrm{DIL}^{2}$ & - & 130 & - \\
$1 \% \mathrm{NaCl}+0.01 \mathrm{M}-\mathrm{MgSO}_{4}$ & - & 140 & - \\
$2 \% \mathrm{NaCl}+0.01 \mathrm{M}-\mathrm{MgSO}_{4}$ & - & 160 &
\end{tabular}

Table 2. Escherichia coli strain C-Ia. Effect of chloramphenicol on the development of osmotic fragility

Standard experiment. At time o the exponentially growing anaerobic culture was diluted into broth with various gas régimes. Chloramphenicol was added at time o in Expt. $a$, 10 min. before dilution (i.e. at time - Io min.) in Expt. $b$. The viable titre at time o $\left(8 \times 10^{5}\right.$ bacteria/ $\mathrm{ml}$. in Expt. $a$, and $10^{6}$ bacteria/ml. in Expt. $b$ ) is set equal to $100 \%$.

\begin{tabular}{|c|c|c|c|c|c|c|c|c|}
\hline \multirow[b]{3}{*}{ Expt. } & \multirow{3}{*}{$\begin{array}{c}\text { Gas } \\
\text { régime }\end{array}$} & \multirow{3}{*}{$\begin{array}{l}\text { Chloram- } \\
\text { phenicol } \\
\text { present } \\
(\mu \mathrm{g} . / \mathrm{ml} .)\end{array}$} & \multicolumn{6}{|c|}{ Viable count in $\%$ of original titre } \\
\hline & & & \multicolumn{2}{|c|}{$\begin{array}{l}\text { At } 30 \text { min. with } \\
\text { dilution in }\end{array}$} & \multicolumn{2}{|c|}{$\begin{array}{l}\text { At } 60 \text { min. with } \\
\text { dilution in }\end{array}$} & \multicolumn{2}{|c|}{$\begin{array}{l}\text { At } 120 \text { min. with } \\
\text { dilution in }\end{array}$} \\
\hline & & & Broth & $\mathrm{H}_{2} \mathrm{O}$ & Broth & $\mathrm{H}_{2} \mathrm{O}$ & Broth & $\mathrm{H}_{2} \mathrm{O}$ \\
\hline$a$ & $\begin{array}{l}\mathrm{N}_{2} \text { only } \\
\mathrm{N}_{2} \text { only } \\
\mathrm{N}_{2} \text { only } \\
\mathrm{N}_{2}+\mathrm{CO}_{2}\end{array}$ & $\begin{array}{l}\text { None } \\
25 \\
50 \\
50\end{array}$ & $\begin{array}{l}190 \\
120 \\
105 \\
190\end{array}$ & $\begin{array}{l}0.1 \\
16 \\
60 \\
55\end{array}$ & - & $\begin{array}{l}- \\
- \\
-\end{array}$ & $\begin{array}{r}63 \\
150 \\
93 \\
87\end{array}$ & $\begin{array}{l}<0 \cdot 1 \\
19 \\
73 \\
66\end{array}$ \\
\hline$b$ & $\begin{array}{l}\mathrm{N}_{2} \text { only } \\
\mathrm{N}_{2} \text { only }\end{array}$ & $\begin{array}{l}\text { None } \\
\text { IOO }\end{array}$ & $\begin{array}{l}210 \\
150\end{array}$ & $\begin{array}{l}2 \cdot 8 \\
170\end{array}$ & $\begin{array}{l}115 \\
190\end{array}$ & $\begin{array}{l}\text { I. } 6 \\
\text { IIO }\end{array}$ & $\begin{array}{r}84 \\
180\end{array}$ & $\mathrm{I} \cdot \mathbf{2}$ \\
\hline
\end{tabular}

Death of the osmotically sensitive bacteria is not a result of the handling involved in the colony-count procedure. In fact, their inviability following the challenge was also shown by end-point titration in broth. The effect of dilution in distilled water could be 
demonstrated immediately: once the dilution in water was made the survival did not vary significantly upon keeping the tube (at room temperature) for as long as $30 \mathrm{~min}$.

Microscopical observation (phase contrast) of bacteria in the osmotically sensitive state did not reveal any gross morphological abnormality. This applied also to such bacteria after dilution in distilled water; in other words, the killing was not due to visible rupture or distortion of the cell envelopes and loss of cytoplasm. Quantitatively, these experiments presented some difficulties, since the bacterial concentration after dilution in distilled water was very low when conditions that best produced the effect were chosen. In some experiments therefore, at various times following $\mathrm{CO}_{2}$ removal, the bacteria, after dilution in either broth or distilled water, were centrifuged down and concentrated more than roo-fold, before being examined and counted in a microscope (Table 3).

\section{Table 3. Escherichia coli strain C-Ia. Recovery of morphologically normal bacteria following inactivation by osmotic challenge}

In a standard experiment, I ml. samples were diluted $\mathrm{I} / 40$ either in broth or in distilled water, assayed by viable count, centrifuged, and resuspended in a small volume of broth to which formalin was added later (Expt. B) or directly in formalin $(0.3 \%$ final formaldehyde concentration) (Expt. A). The titres of these suspensions were determined under a microscope with a Petroff-Hausser counting chamber (also by viable count in Expt. B).

\begin{tabular}{|c|c|c|c|c|}
\hline Expt. & $\begin{array}{l}\text { Time (min.) } \\
\text { after beginning } \\
\text { of } \mathrm{CO}_{2} \\
\text { deprivation }\end{array}$ & $\begin{array}{c}\text { Percentage } \\
\text { survival to } \\
\text { osmotic } \\
\text { challenge }\end{array}$ & $\begin{array}{l}\text { Percentage effi- } \\
\text { ciency of the } \\
\text { concentration by } \\
\text { centrifugation } \\
\text { (unchallenged } \\
\text { bacteria) }\end{array}$ & $\begin{array}{l}\text { Percentage relative } \\
\text { recovery of } \\
\text { challenged } \\
\text { bacteria by } \\
\text { microscopic } \\
\text { count }\end{array}$ \\
\hline & & $(I)^{*}$ & $(2 a) \dagger$ & (3) $\S$ \\
\hline $\mathbf{A}$ & $\begin{array}{l}30 \\
60\end{array}$ & $\begin{array}{l}1 \cdot 0 \\
2 \cdot 8 \\
2 \cdot 0\end{array}$ & $\begin{array}{l}39 \\
57\end{array}$ & $\begin{array}{l}27 \\
77 \\
68\end{array}$ \\
\hline & $\begin{array}{r}90 \\
120\end{array}$ & $\begin{array}{l}3.0 \\
8.7\end{array}$ & $\begin{array}{c}49 \\
46 \\
(2 b) \ddagger\end{array}$ & $\begin{array}{l}68 \\
80\end{array}$ \\
\hline B & $\begin{array}{r}30 \\
90 \\
120\end{array}$ & $\begin{array}{l}1 \cdot 4 \\
4.9 \\
6.7\end{array}$ & $\begin{array}{l}54 \\
70 \\
36\end{array}$ & $\begin{array}{r}100 \\
78 \\
76\end{array}$ \\
\hline
\end{tabular}

* $(\mathrm{I})=100 \times$ (viable count following dilution in $\left.\mathrm{H}_{2} \mathrm{O}\right) /($ viable count following dilution in broth).

$\dagger(2 a)=100 \times$ (total count in concentrated suspension, corrected for the volume change)/(viable count before concentration).

$\ddagger(2 b) 100 \times$ (viable count in concentrated suspension, corrected for the volume change)/(viable count before concentration).

$\S(3)=100 \times($ total count in concentrated, challenged suspension)/(total count in concentrated, unchallenged suspension).

The efficiency of the concentration process performed thus was low and variable (possibly due to bacteria sticking to the walls of the centrifuge tube, partially washing off the pellet, and the large error in estimating pellet volume). Nevertheless, the apparent morphological integrity of the majority of the bacteria inactivated by the osmotic challenge was clearly indicated by the data.

Another experiment (Table 4) also indicated that killing of osmotically sensitive bacteria by dilution in distilled water was not accompanied by a mass leakage of cell contents. The $\beta$-galactosidase activity of bacteria first challenged by dilution in water 
and then concentrated by centrifugation (with removal of the supernatant) was essentially identical with that of unchallenged bacteria.

In other experiments, all the Escherichia coli c derivatives listed in Methods, the two c600 derivatives of $E$. coli K-I2, and the Serratia marcescens strain were tested for osmotic fragility following anaerobic $\mathrm{CO}_{2}$ deprivation; they all gave the effect like strain C-Ia. But the effect could not be demonstrated with any of the four lines of $E$. coli $\mathrm{B}$ tested, even though the absolute requirement for $\mathrm{CO}_{2}$ under anaerobic conditions could be demonstrated even with $E$. coli $\mathbf{B}$. Attempts to demonstrate a similar osmotic fragility with the two biotin-requiring mutants when starved of biotin under aerobic conditions (in the presence of $\mathrm{CO}_{2}$ ) were completely unsuccessful.

\section{Table 4. Escherichia coli Strain C-Ia. Recovery of $\beta$-galactosidase activity in $\mathrm{CO}_{2}$-deprived, osmotically challenged bacteria}

Standard experiment. Bacteria were grown however in modified LB (glucose replaced by $0.25 \%$ lactose) to obtain full induction of $\beta$-galactosidase. The transfer to $\mathrm{N}_{2}$-only bubbled broth involved a six-fold dilution. The challenge consisted of a fifty-fold dilution into $\mathrm{H}_{2} \mathrm{O}$. A similar dilution in ordinary LB served as control. Following these dilutions, and the viable count assays, the samples were reconcentrated by centrifugation and resuspended in buffer, before assaying for enzyme activity. To assure a good recovery in the concentration step, a small volume of a concentrated suspension of mutant bacteria unable to synthesize $\beta$-galactosidase was added to each sample as carrier. An equal volume of double strength $\mathrm{LB}$ was added to the $\mathrm{CO}_{2}$-starved sample in $\mathrm{H}_{2} \mathrm{O}$ before centrifugation to make the physical environment (which might affect pellet formation, etc.) identical with that of the control in broth. Comparable suspensions of carrier bacteria alone were used as blanks. The concentration of carrier bacteria in the final enzyme assay mixture was of the order of $10^{7} / \mathrm{ml}$.

Viable count $/ \mathrm{ml}$. culture

No. of bacteria expected to be present in $0.1 \mathrm{ml}$. of the re-concentrated samples (assuming full recovery and neglecting carrier bacteria)

Extinction reading in the enzyme assay (for a layer thickness of $1 \cdot 0 \mathrm{~cm}$.)
Anaerobic culture

\begin{tabular}{|c|c|c|c|}
\hline \multicolumn{2}{|c|}{$\begin{array}{l}\text { Exponentialy growing } \\
\text { in the presence of } \mathrm{CO}_{2}\end{array}$} & \multicolumn{2}{|c|}{$\begin{array}{l}\text { Diluted } \mathrm{I} / 6 \text { and main- } \\
\text { tained for } \mathrm{I} \mathrm{hr} \text { in the } \\
\text { absence of } \mathrm{CO}_{2}\end{array}$} \\
\hline $\begin{array}{l}\text { Diluted } \\
\text { in broth }\end{array}$ & $\begin{array}{l}\text { Diluted } \\
\text { in } \mathrm{H}_{2} \mathrm{O}\end{array}$ & $\begin{array}{l}\text { Diluted } \\
\text { in broth }\end{array}$ & $\begin{array}{l}\text { Diluted } \\
\text { in } \mathrm{H}_{2} \mathrm{O}\end{array}$ \\
\hline $2.6 \times 10^{8}$ & $3.0 \times 10^{8}$ & $4.3 \times 10^{7}$ & $2.5 \times 10^{6}$ \\
\hline $5.2 \times 10^{8}$ & $6.0 \times 10^{6}$ & $5.4 \times 10^{6}$ & $\left(5.4 \times 10^{6}\right)$ \\
\hline 0.34 & 0.33 & 0.72 & 0.65 \\
\hline
\end{tabular}

\section{DISCUSSION}

The necessity of an external supply of $\mathrm{CO}_{2}$ for the growth of many bacteria under certain conditions was shown long ago (see Gladstone, Fildes \& Richardson, 1935, for early references). Later work (Lwoff \& Monod, 1947; Ajl \& Werkman, 1949; McLean \& Purdie, 1952; Wiame \& Bourgeois, 1955) showed that the addition of certain compounds to simple defined media decreased drastically the $\mathrm{CO}_{2}$ requirement and its incorporation. Several $\mathrm{CO}_{2}$-dependent, metabolic reactions could thus be identified. Not all essential $\mathrm{CO}_{2}$-requiring reactions were detected in these experiments, since in several cases a residual $\mathrm{CO}_{2}$-dependence could not be eliminated. $\mathrm{A}$ technical difficulty arises from the fact that both $\mathrm{CO}_{2}$-fixing and $\mathrm{CO}_{2}$-releasing reactions 
occur in a cell, so that the extent of the requirement for an external $\mathrm{CO}_{2}$ supply depends on the balance of the two sets of reactions under the cultural conditions used, and on the efficiency with which intracellular $\mathrm{CO}_{2}$ diffuses and is exchanged with extracellular $\mathrm{CO}_{2}$. To establish experimentally conditions of absolute $\mathrm{CO}_{2}$ deprivation it is thus necessary to maintain a sufficiently high rate of removal of the $\mathrm{CO}_{2}$ produced by the cells.

In our experiments with a nutritionally rich broth as culture medium, anaerobic conditions, and sufficiently low concentrations of bacteria, we succeeded in showing an absolute requirement for external $\mathrm{CO}_{2}$ with all the bacterial strains examined. All the tests were done with exponentially growing cultures, thereby excluding the complexities of growth initiation by resting bacteria. We did not succeed in showing the requirement in similar cultures growing aerobically, presumably because of a higher rate of $\mathrm{CO}_{2}$ production under such conditions.

The broth we used was expected to contain all amino acids and nucleic acid bases that the bacteria would need if the corresponding synthetic pathways were blocked. Under these conditions the factor, or factors, which cannot be synthesized in the absence of $\mathrm{CO}_{2}$ must either be absent from the medium or unavailable to the bacteria because of difficulties in uptake. In recent years reactions which require $\mathrm{CO}_{2}$ have been demonstrated in the synthesis (and degradation) of long-chain fatty acids. Since lipids are an important element in the structure of cell envelopes, it seems reasonable to suggest that the osmotic fragility observed by us might result from limitation or defects in the synthesis of fatty acids, leading to an abnormal composition of the cell envelopes, and consequently to extreme sensitivity to osmotic challenge. Since biotin is the coenzyme involved in the carboxylation reactions recalled above, we thought that it might be possible to produce a similar osmotic fragility, even in the presence of $\mathrm{CO}_{2}$, by starving bacteria of biotin. In fact, there are indications in the literature (see Gavin \& Umbreit, 1965) that deprivation of biotin affects the permeability of the bacteria. Our experiments in this direction were, however, unsuccessful.

Many effects of abrupt changes in the osmotic pressure of the suspending medium have been described in the bacteriological literature (see, for example, among the latest, Bayer (1967), and Heppel, (1967)). In terms of viability, the effect produced in our experiments can be very drastic, even following relatively small changes in solute concentration of the medium. The effect is not necessarily connected with that described by Meynell (1958), in which bacteria were challenged by dilution in ice-cold water, then stored cold for several hours before being assayed. We were able to reproduce Meynell's results with Escherichia coli c. Unlike the osmotic fragility following $\mathrm{CO}_{2}$ deprivation, Meynell's effect was not immediately demonstrable following dilution in cold water; storage was essential for its manifestation. We have no explanation for the absence of osmotic fragility following $\mathrm{CO}_{2}$ deprivation in $E$. coli strain $\mathrm{B}$. It might be rewarding to study the inheritance of this difference in crosses between strains $\mathrm{B}$ and $\mathrm{C}$, or B and K-I2.

This work was aided by a joint grant from the Swedish Medical and Natural Sciences Research Councils, and the Swedish Cancer Society, and by a travel grant to one of us (B.K.C.) by the former Central Committee for Technical Assistance of the Swedish Institute. 


\section{REFERENCES}

Adelberg, E. A., Mandel, M. \& Chen, G. C. C. (1965). Optimal conditions for mutagenesis by $N$-methyl- $N^{\prime}$-nitro- $N$-nitrosoguanidine in Escherichia coli K-12. Biochem. biophys. Res. Comm. I8, 788.

AJl, S. J. \& Werkman, C. H. (1949). Anaerobic replacement of carbon dioxide. Proc. Soc. exp. Biol. Med. 70, 522.

APPLEYARD, R. K. (1954). Segregation of lambda lysogenicity during bacterial recombination in Escherichia coli K-12. Genetics 39, 429.

BAYER, M. E. (1967). Response of cell walls of Escherichia coli to a sudden reduction of the environmental osmotic pressure. J. Bact. 93, I104.

BertanI, G. (195I). Studies on lysogenesis. I. The mode of phage liberation by lysogenic Escherichia coli. J. Bact. 62, 293.

Bertani, G. \& Six, E. (1958). Inheritance of prophage P2 in bacterial crosses. Virology 6, 357.

Bertani, G., TORHEIM, B. \& LAURENT, T. (1967). Multiplication in Serratia of a bacteriophage originating from Escherichia coli: lysogenization and host controlled variation. Virology 32, 619.

BRENNER, S. \& BECKWITH, J. R. (I965). Ochre mutants, a new class of suppressible nonsense mutants. J. molec. Biol. r3, 629.

COHEN, D. (1959). A variant of phage P2 originating in Escherichia coli strain B. Virology 7, 12.

Del Campillo-Campbell, A., Kayajanian, G., Campbell, A. \& Adhya, S. (1967). Biotin-requiring mutants of Escherichia coli K-I2. J. Bact. 94, 2065.

GAVIN, J. J. \& UMBREIT, W. W. (I965). Effect of biotin on fatty acid distribution in Escherichia coli. J. Bact. 89, 437.

Gladstone, G. P., Fildes, P. \& Richardson, G. M. (I935). Carbon dioxide as an essential factor in the growth of bacteria. Br.J. exp. Path. 16, 335.

HEPPEL, L. A. (1967). Selective release of enzyme from bacteria. Science, N.Y. 156, I451.

LwoFf, A. \& MONOD, J. (1947). Essai d'analyse du rôle de l'anhydride carbonique dans la croissance microbienne. Annls Inst. Pasteur, Paris 73, 323.

Mandell, J. \& GreenBerg, J. (1960). A new chemical mutagen for bacteria, I-methyl-3-nitro-Initrosoguanidine. Biochem. biophys. Res. Commun. 3, 575.

MCLean, D. J. \& PURdie, E. F. (1952). Effect of amino acids, purines and pyrimidines on carbon dioxide fixation by Serratia marcescens. J. biol. Chem. r97, 539.

MeYNell, G. G. (1958). The effect of sudden chilling on Escherichia coli. J. gen. Microbiol. 19, 380.

SASAKI, I. \& BERTANI, G. (I965). Growth abnormalities in Hfr derivatives of Escherichia coli strain C. J. gen. Microbiol. 40, 365.

WALlENFELs, K. (1962). $\beta$-galactosidase (crystalline). Meth. Enzymol. 5, 2 I 2.

WIAME, J. M. \& BouRGEOIS, S. (1955). Le rôle de l'anhydride carbonique dans les croissances bactériennes. Biochem. biophys. Acta 18, 269.

WITKIN, E. M. (1947). Genetics of resistance to radiation in Escherichia coli. Genetics 32, 22 I. 